\title{
Recovery and Recycle of Irradiated Low-Enriched Uranium from the Production of ${ }^{99} \mathrm{Mo}$
}

Chemical and Fuel Cycle Technologies Division 


\begin{abstract}
About Argonne National Laboratory
Argonne is a U.S. Department of Energy laboratory managed by UChicago Argonne, LLC

under contract DE-AC02-06CH11357. The Laboratory's main facility is outside Chicago,

at 9700 South Cass Avenue, Lemont, Illinois 60439. For information about Argonne

and its pioneering science and technology programs, see www.anl.gov.
\end{abstract}

\title{
DOCUMENT AVAILABILITY
}

Online Access: U.S. Department of Energy (DOE) reports produced after 1991 and a growing number of pre-1991 documents are available free at OSTI.GOV (http://www.osti.gov/),

a service of the US Dept. of Energy's Office of Scientific and Technical Information.

\author{
Reports not in digital format may be purchased by the public \\ from the National Technical Information Service (NTIS): \\ U.S. Department of Commerce \\ National Technical Information Service \\ 5301 Shawnee Road \\ Alexandria, VA 22312 \\ www.ntis.gov \\ Phone: (800) 553-NTIS (6847) or (703) 605-6000 \\ Fax: (703) 605-6900 \\ Email: orders@ntis.gov
}

\author{
Reports not in digital format are available to DOE and DOE contractors \\ from the Office of Scientific and Technical Information (OSTI): \\ U.S. Department of Energy \\ Office of Scientific and Technical Information \\ P.O. Box 62 \\ Oak Ridge, TN 37831-0062 \\ www.osti.gov \\ Phone: (865) 576-8401 \\ Fax: (865) 576-5728 \\ Email: reports@osti.gov
}

\footnotetext{
Disclaimer

This report was prepared as an account of work sponsored by an agency of the United States Government. Neither the United States Government nor any agency thereof, nor UChicago Argonne, LLC, nor any of their employees or officers, makes any warranty, express or implied, or assumes any legal liability or responsibility for the accuracy, completeness, or usefulness of any information, apparatus, product, or process disclosed, or represents that its use would not infringe privately owned rights. Reference herein to any specific commercial product, process, or service by trade name, trademark, manufacturer, or otherwise, does not necessarily constitute or imply its endorsement, recommendation, or favoring by the United States Government or any agency thereof. The views and opinions of document authors expressed herein do not necessarily state or reflect those of the United States Government or any agency thereof. Argonne National Laboratory, or UChicago Argonne, LLC.
} 
ANL-21/22

\section{Recovery and Recycle of Irradiated Low-Enriched Uranium from the Production of ${ }^{99} \mathrm{Mo}$}

prepared by

M. Alex Brown, George F. Vandegrift, Jackie M. Copple, and Peter Tkac

Chemical and Fuel Cycle Technologies Division, Argonne National Laboratory

Prepared for the National Nuclear Security Administration -

Material Management and Minimization

April 2021 


\section{Contents}

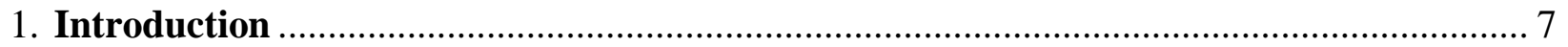

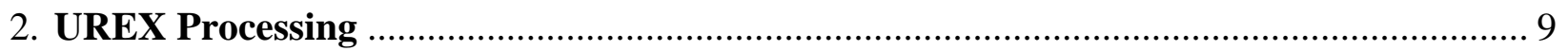

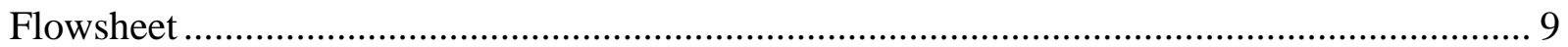

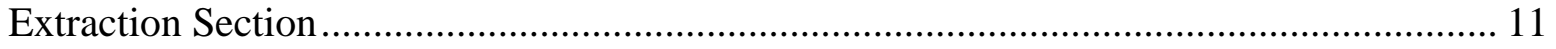

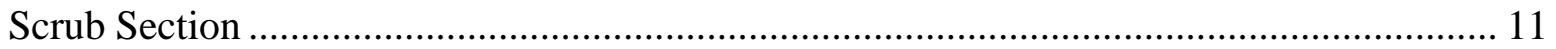

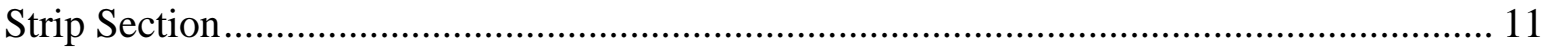

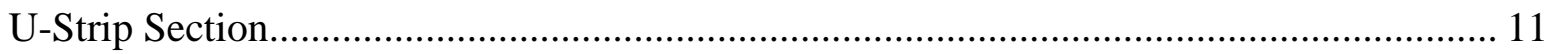

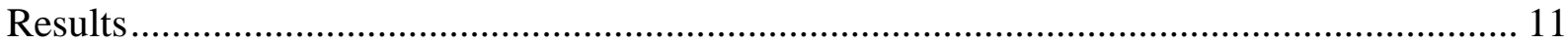

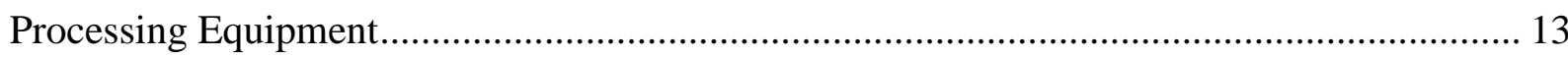

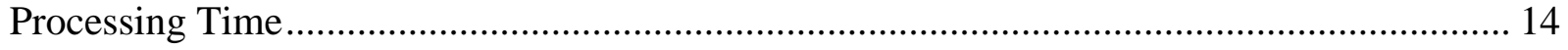

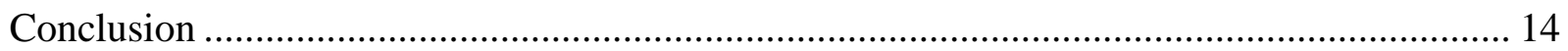

3. Conversion of the Uranium Product from the UREX Process to Uranium Metal........... 16

Conversion of the Uranium Product from the UREX Process to Uranium Dioxide ................ 16

Conversion of Uranium Dioxide to Uranium Metal .......................................................... 20

Baseline Conversion Process ................................................................................... 20

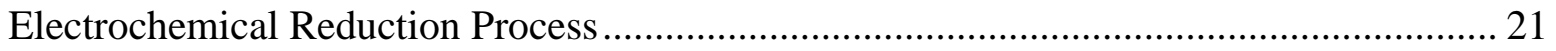

Uranium Metal to Targets ....................................................................................... 21

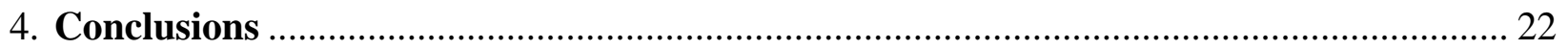

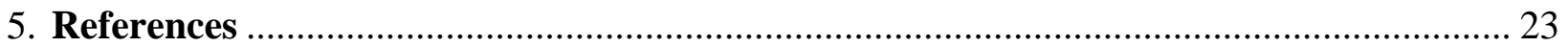

\section{Figures}

Figure 1. Process flowsheet sections. ............................................................................ 10

Figure 2. Decontamination factors of representative metal ions of important oxidation states

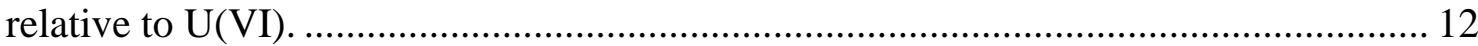

Figure 3. Equilibrium concentration profile for $\mathrm{U}(\mathrm{VI})$ and $\mathrm{Pu}(\mathrm{IV})$ at each stage...................... 13

Figure 4: Photograph of a 20-stage bank of 2-cm centrifugal contactors. ................................ 14

Figure 5. Schematic of calciner equipment........................................................................ 17

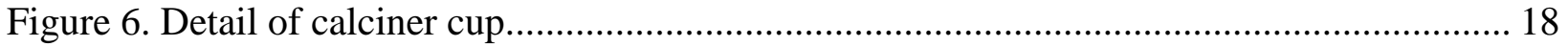

Figure 7. Overall view of lab-scale experimental calcining system..................................... 18

\section{Tables}

Table 1. Composition of the feed, raffinate, and U product from the AMUSE calculation.......... 9

Table 2. Stage, composition, and relative flow rate of each flowsheet section.......................... 10 


\begin{abstract}
Technetium-99m $\left({ }^{99 m} \mathrm{Tc}\right)$, the daughter (decay product) of molybdenum-99 $\left({ }^{99} \mathrm{Mo}\right)$, is the most commonly used medical radioisotope in the world. ${ }^{99}$ Mo is produced primarily from the fissioning of $235 \mathrm{U}$. A potential future producer, Eden Radioisotopes, is planning to irradiate low-enriched-uranium metal-foil targets for production of ${ }^{99} \mathrm{Mo}$. Their plan is to recover, purify, and recycle the irradiated LEU in a new set of targets inside their facility. This study assesses processes to (1) purify and recycle uranium following ${ }^{99}$ Mo recovery and (2) convert the uranium to metal for subsequent foil production and target fabrication. A UREX (uranium recovery by extraction) liquid-liquid extraction flowsheet that utilizes centrifugal contactors was developed using the Argonne model for universal solvent extraction (AMUSE) to recover and purify the uranium. The calculated flowsheet predicted high decontamination from $\mathrm{Pu}$ and most fission products and $>99.99 \%$ recovery of uranium. Suggestions for conversion of the UREX U-product (uranyl nitrate in dilute nitric acid) to U metal were provided based on literature studies and earlier laboratory studies performed at Argonne National Laboratory.
\end{abstract}

\title{
1. Introduction
}

Technetium-99m $\left({ }^{99 m} \mathrm{Tc}\right)$, the daughter (decay) product of molybdenum-99 $\left({ }^{99} \mathrm{Mo}\right)$, is the most commonly used medical radioisotope in the world. It is used for approximately 25 million medical diagnostic procedures annually, comprising some $80 \%$ of all nuclear medicine procedures [11].

The United States Department of Energy (DOE) National Security Agency's (NNSA's) Office of Material Management \& Minimization $\left(\mathrm{M}^{3}\right)$ is supporting a number of domestic entities in their pursuit of medical isotope generator pair ${ }^{99} \mathrm{Mo} /{ }^{99 m} \mathrm{Tc}$ production without the use of high-enriched uranium (HEU)[17], and Argonne National Laboratory (Argonne) is providing technical assistance to many of these entities. One of these potential future producers is Eden Radioisotopes (Eden). Eden is developing a Triga-sized, all-target reactor system licensed from Sandia National Laboratories as a direct result of their involvement in ${ }^{99} \mathrm{Mo}$ in the $1990 \mathrm{~s}$. This reactor system uses the Argonne-designed annular LEU-foil target for the production of fissionproduct ${ }^{99}$ Mo. Further information on the Argonne-designed target can be found in the compendium report on NNSA-funded research on this target [21].

The Eden LEU targets will contain approximately $127 \mathrm{~g}$ of LEU and be irradiated at $30 \mathrm{~kW}$ for up to 3 weeks, consuming $0.2-0.5 \mathrm{~g}$ of the $25 \mathrm{~g}$ of $\mathrm{U}-235$ present in the target. The annular target utilizes two aluminum tubes that form the outer and inner walls of the cladding cylinder. Held between the walls is a 250 - $\mu$ m thick uranium foil covered on all sides by a thin Ni-foil fission barrier. Eden expects to process up to five targets per process batch within a few hours of their discharge from the reactor, meeting U.S. ${ }^{99}$ Mo demand with three process batches per day [7]. Argonne is working with Eden to identify the best chemical processes to purify ${ }^{99}$ Mo from their irradiated targets and recover LEU material for use in another target irradiation. 
The goals of increasing its market competitiveness and reducing waste generation make recovering LEU for additional irradiations a high priority for Eden. In addition to uranium, these irradiated targets contain aluminum cladding, irradiated nickel, and adsorption and fission products, all of which must be removed to allow recycling of the uranium. The cladding is mechanically removed before the uranium foil and Ni fission-recoil barrier are dissolved for molybdenum recovery. Once the molybdenum is recovered from the dissolver solution, uranium recovery and purification can begin.

Solvent extraction with tri-n-butyl phosphate (TBP) is the ideal approach for purifying bulk quantities of uranium as well as recovering the target material as uranyl nitrate in dilute nitric acid [6]. The chemistry is based on the solvating mechanism of TBP with selected IV and VI valence cations in the presence of nitrate counter ions in slightly acidic media. The primary extractable ions are $\mathrm{U}(\mathrm{VI}), \mathrm{Pu}(\mathrm{IV}), \mathrm{Np}(\mathrm{IV})$, and $\mathrm{Np}(\mathrm{VI})$; notable co-extractables include $\mathrm{Tc}(\mathrm{VII})$, $\mathrm{Zr}, \mathrm{Ru}, \mathrm{I}$, and nitric acid. The remaining transuranics, fission products, and activation products are held back in the raffinate. To separate $\mathrm{U}$ from these other actinides and $\mathrm{Zr}$ and $\mathrm{Ru}$, the uranium extraction (UREX) process uses the complexation of acetohydroxamic acid (AHA) with $\mathrm{Np}(\mathrm{IV}), \mathrm{Pu}(\mathrm{IV}), \mathrm{Zr}$, and $\mathrm{Ru}$. It also has the ability to reduce $\mathrm{Np}(\mathrm{VI})$ to the unextractable $\mathrm{Np}(\mathrm{V})$. The U(VI) is poorly complexed by AHA and extracts into the organic phase [19]. Extracted AHA can be removed from the organic phase by scrubbing with nitric acid, and uranyl nitrate can be stripped from the solvent using dilute nitric acid.

The Argonne model for universal solvent extraction (AMUSE) code can predict steady-state extraction behavior for a number of liquid-liquid extraction processes that employ centrifugal contactors, mixer-settlers, or pulse columns [7]. The code relies on thermodynamic complexation equilibria with aqueous-ion activities, a mass-balance algorithm, and stage efficiencies and other-phase carryover from user-specified inputs. This report documents the Argonne study to assess processes to (1) purify and recycle uranium following ${ }^{99}$ Mo recovery and (2) convert the uranium to metal for subsequent foil production and target fabrication. These topics are discussed in the following two sections. 


\section{UREX Processing}

The initial target materials in this study were annular LEU-foils with a Ni fission barrier and Al cladding. Following irradiation, the Al cladding is mechanically removed in a hot cell. The LEU foil and Ni barrier are then dissolved in nitric acid diluted to an appropriate $\mathrm{pH}$ and fed through a Mo-recovery column (usually composed of an inorganic metal oxide sorbent). The column is washed with dilute acid to remove any residual bulk uranium and most fission products. The molybdenum product from the column then undergoes further purification.

In Eden's current processing scheme, the eluent and washes from the recovery column are combined and neutralized with $\mathrm{NaOH}$ to drive the formation of insoluble uranyl-hydroxide. The majority of fission product and actinide cations save the noble gasses, while Mo, Tc, Cs, Rb, and I are carried down with uranium. Since the extent to which the fission products are carried by the uranyl-hydroxide is unknown, we assumed a conservative $90 \%$ co-precipitation. The uranylhydroxide cake is washed with dilute alkali to further remove soluble fission products and dissolved in nitric acid to generate a $1 \mathrm{M}$ hydrogen-ion concentration.

The uranium and nickel content is based on the following parameters: 6 targets (U-foil, $127 \mathrm{~g}$ LEU/target, 3 g-Ni/target) dissolved in $3.2 \mathrm{~L}$ of $1 \mathrm{M} \mathrm{HNO}_{3}$. The fission product concentrations were calculated using Oak Ridge isotope generation (ORIGEN) simulations with 21-day burnup, $30 \mathrm{~kW}$, and 24-hour decay (Eden Radioisotopes, LLC, pers. comm.).

\section{Flowsheet}

The composition of the UREX feed entered into AMUSE is presented in Table 1. Because the AMUSE code does not contain data for the extraction and complexation of $\mathrm{Ni}^{2+}$, we used $\mathrm{Sr}^{2+}$ as a surrogate; both cations are poorly complexed by AHA and poorly extracted by TBP.

Table 1. Composition of the feed, raffinate, and U product from the AMUSE calculation.

\begin{tabular}{|c|c|c|c|}
\hline \multicolumn{4}{|c|}{ Concentration, $\mathrm{M}$} \\
\hline Species & Feed & Raffinate & U-Product \\
\hline $\mathbf{H}^{+}$ & $1.00 \mathrm{E} 0$ & 7.73E-1 & $2.26 \mathrm{E}-2$ \\
\hline $\mathrm{NO}_{3}{ }^{-}$ & $3.22 \mathrm{E} 0$ & $9.38 \mathrm{E}-1$ & 4.30E-1 \\
\hline AHA & 0 & $1.87 \mathrm{E}-2$ & $1.45 \mathrm{E}-10$ \\
\hline $\mathbf{B a}^{2+}$ & $6.90 \mathrm{E}-4$ & $5.16 \mathrm{E}-4$ & 9.83E-30 \\
\hline $\mathrm{Np}^{4+}$ & $7.10 \mathrm{E}-5$ & 5.31E-5 & $3.25 \mathrm{E}-25$ \\
\hline $\mathbf{P u}^{4^{+}}$ & $3.70 \mathrm{E}-4$ & $2.77 \mathrm{E}-4$ & $2.40 \mathrm{E}-15$ \\
\hline $\mathbf{R h}^{3+}$ & $4.20 \mathrm{E}-5$ & $3.14 \mathrm{E}-5$ & $3.26 \mathrm{E}-23$ \\
\hline $\mathbf{R} \mathbf{u}^{3+}$ & $9.60 \mathrm{E}-4$ & $6.75 \mathrm{E}-4$ & $5.78 \mathrm{E}-8$ \\
\hline $\mathrm{Sr}^{2+*}$ & $1.00 \mathrm{E}-1$ & 7.49E-2 & $1.42 \mathrm{E}-27$ \\
\hline $\mathrm{TcO}_{4}^{-}$ & $3.50 \mathrm{E}-4$ & $1.87 \mathrm{E}-6$ & 7.07E-5 \\
\hline
\end{tabular}




\begin{tabular}{|c|c|c|c|}
\hline \multicolumn{4}{|c|}{ Concentration, $\mathbf{M}$} \\
\hline Species & Feed & Raffinate & U-Product \\
\hline $\mathbf{U O}_{2}{ }^{2+}$ & $1.00 \mathrm{E} 0$ & $5.60 \mathrm{E}-12$ & $2.03 \mathrm{E}-1$ \\
\hline $\mathbf{Y}^{\mathbf{3 +}^{+}}$ & $3.90 \mathrm{E}-4$ & $2.92 \mathrm{E}-4$ & $5.63 \mathrm{E}-30$ \\
\hline $\mathbf{Z r O}^{2+}$ & $3.10 \mathrm{E}-3$ & $2.32 \mathrm{E}-3$ & $2.47 \mathrm{E}-28$ \\
\hline
\end{tabular}

* Adjusted to 0.1M as a surrogate for Ni(II) in AMUSE.

The conceptualized flowsheet is shown in Figure 1. The compositions of the process feeds, number of stages per section, and relative flow rates are listed in Table 2. Only the concentration of nitric acid is given for the feed.

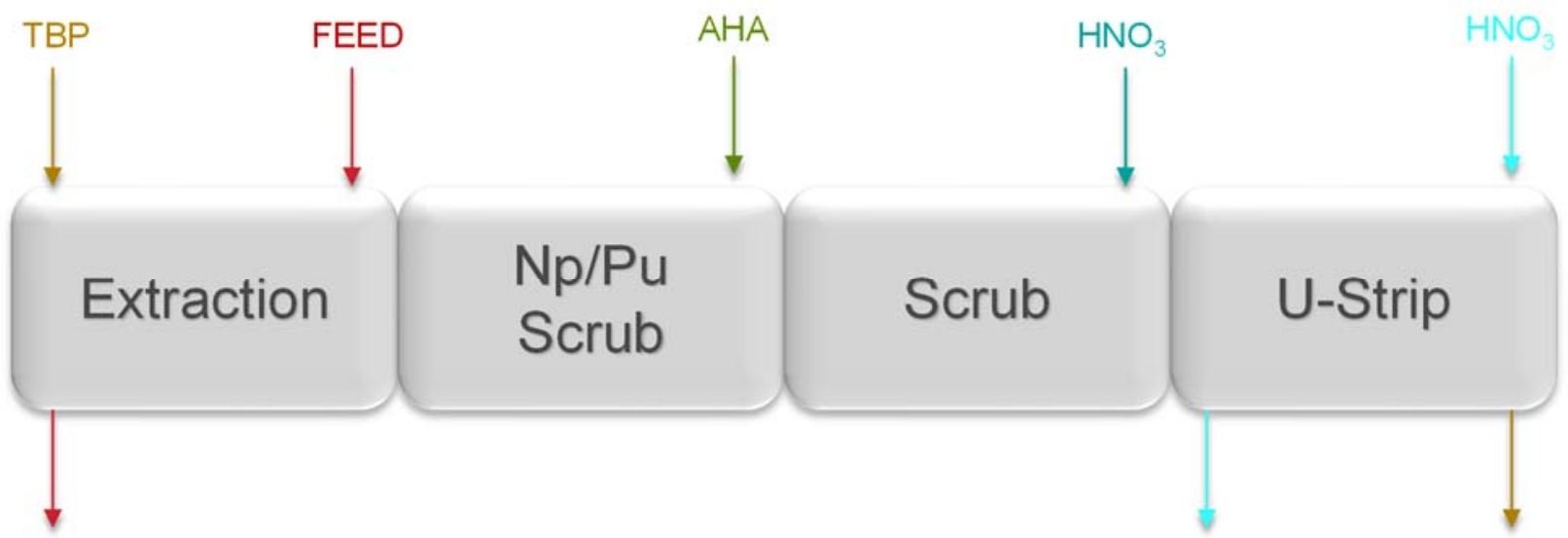

Figure 1. Process flowsheet sections.

Table 2. Stage, composition, and relative flow rate of each flowsheet section.

\begin{tabular}{|c|c|c|c|}
\hline Section & Stages & Input Concentrations & $\begin{array}{c}\text { Relative flow rates of feeds to } \\
\text { each section (O, A) }\end{array}$ \\
\hline Extraction & 8 & $\begin{array}{c}1 \mathrm{M} \mathrm{HNO}_{3}{ }^{\mathrm{b}} \\
30 \% \mathrm{TBP} \text { in n-dodecane }\end{array}$ & $2.8,1$ \\
\hline $\mathrm{Np} / \mathrm{Pu} \mathrm{Scrub}$ & 11 & $0.5 \mathrm{M} \mathrm{AHA}+0.1 \mathrm{M} \mathrm{HNO}_{3}$ & $0,0.05$ \\
\hline Scrub & 7 & $0.3 \mathrm{M} \mathrm{HNO} 3$ & $0,0.3$ \\
\hline U-Strip & 10 & $0.01 \mathrm{M} \mathrm{HNO}_{3}$ & $0,4.9$ \\
\hline
\end{tabular}

Fresh stream flow rate entering each section. There are four aqueous streams and one organic stream entering the contactor

b Only nitric acid concentration is shown here. See Table 1 for full composition of extraction feed. 


\section{Extraction Section}

The first contact is the extraction section, where the bulk of the $\mathrm{U}(\mathrm{VI})$, a fraction of the $\mathrm{Pu}(\mathrm{IV})$, and the $\mathrm{Np}(\mathrm{IV}, \mathrm{VI})$, Tc, Ru, Zr, and I are extracted into the organic phase. The aqueous feed enters the contactor at stage 8, and the organic phase (solvent) enters at stage 1 at a relative flow rate of 2.8. They flow countercurrently to each other, with the aqueous solution (raffinate) leaving the contactor at stage 1 . Most of the fission products are not extracted and leave the contactor in the raffinate.

\section{Scrub Section}

Once loaded with uranium, the solvent is routed to the Np/Pu scrub section starting at stage 9, where sufficient concentrations of $\mathrm{AHA}$ in dilute $\mathrm{HNO}_{3}$ bring down the $\mathrm{Np}, \mathrm{Pu}$, and other cations that are complexed by AHA into the aqueous phase. The $\mathrm{Np} / \mathrm{Pu}$ scrub feed solution enters the contactor at stage 19 at a relative flow rate of 0.05 and runs countercurrent to the solvent, eventually joining the feed at stage 8 . Throughout the extraction section, the uranyl nitrate remains in the loaded organic phase. The scrubbed $\mathrm{Np}, \mathrm{Pu}, \mathrm{Zr}$, and $\mathrm{Ru}$ travel back into the extraction section and exit the contactor in the raffinate.

\section{Strip Section}

The scrub section removes residual AHA from the solvent before the solvent moves into the strip section, where it is contacted with dilute $\mathrm{HNO}_{3}$. The scrub feed enters the contactor at stage 26 at a relative flow rate of 0.3 . It flows countercurrent to the loaded solvent through the $\mathrm{Np} / \mathrm{Pu}$ scrub and eventually leaves the contactor at stage 1 . The total raffinate relative flow rate at steady state is equal to $1+0.05+0.3=1.35$.

\section{U-Strip Section}

Finally, uranyl nitrate is recovered in the U-strip section with dilute $\mathrm{HNO}_{3}$, which enters the contactor at stage 36 with a relative flow rate of 4.9 and leaves the contactor at stage 27 as the Uproduct solution. Table 1 also reports the calculated compositions of the raffinate and U-product solutions.

\section{Results}

Decontamination factors (DFs) for representative metal ions of important oxidation states and extraction chemistry, $M$, were defined in terms of the uranium concentrations in the initial (i) feed and the final (f) product, respectively, as shown in equation 1.

$$
\mathrm{DF}=\left([M]_{\mathrm{i}} /[U]_{\mathrm{i}}\right) /\left([M]_{\mathrm{f}} /[U]_{\mathrm{f}}\right)
$$


The calculated DFs are plotted in Figure 2. The process exhibited excellent removal of most 2+ and 3+ ions, due in part to the low default distribution ratio of 0.001 in AMUSE for species that are known to be unextractable by TBP. These elements include alkali and alkaline earth metals, lanthanides, and $\mathrm{Y}$. Most transition metals and p-block elements are also removed during the extraction step, including $\mathrm{Mn}, \mathrm{Fe}, \mathrm{Co}, \mathrm{Ni}, \mathrm{Cu}, \mathrm{Zn}, \mathrm{Ga}, \mathrm{Ge}, \mathrm{As}$, Se, Br, Ag, Cd, In, Sn, Sb, and Te. The complexing of AHA and high loading of the TBP solvent with $\mathrm{U}(\mathrm{VI})$ contributes to the high $\mathrm{DF}$ for fission products that are extractable by TBP (e.g., $\mathrm{Zr}, \mathrm{Rh}$, and $\mathrm{Ru}$ ). The tetravalent actinides $\mathrm{Np}(\mathrm{IV})$ and $\mathrm{Pu}(\mathrm{IV})$ were sufficiently scrubbed from the solvent using AHA; the DF for $\mathrm{Pu}(\mathrm{IV})$ was $>10^{10}$.

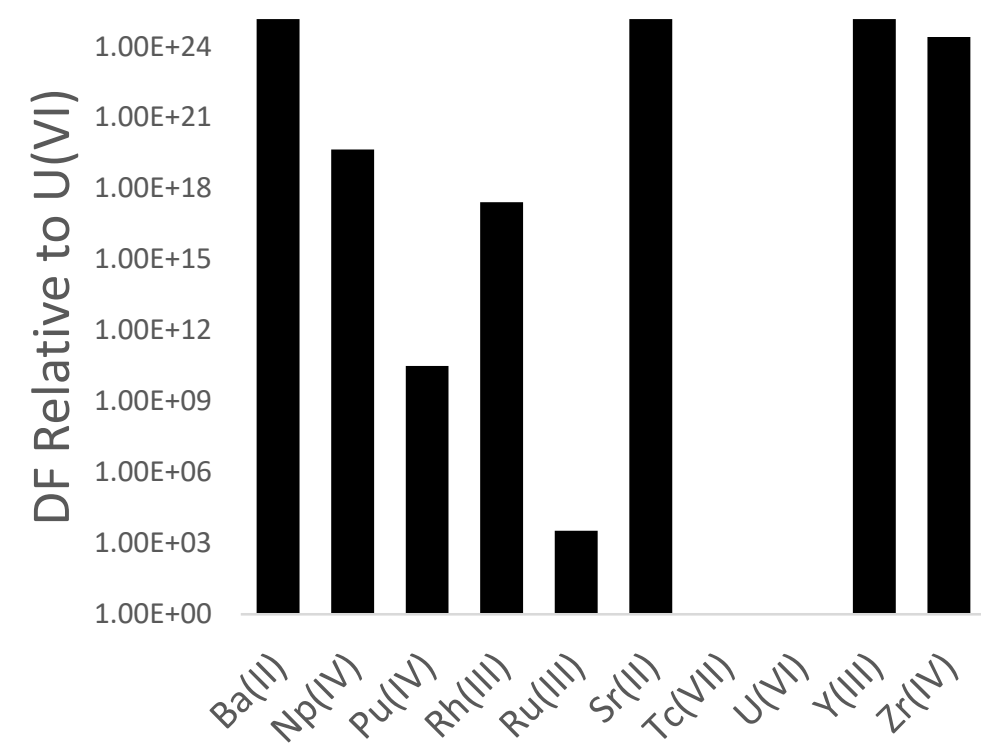

Figure 2. Decontamination factors of representative metal ions of important oxidation states relative to $\mathrm{U}(\mathrm{VI})$.

The equilibrium stage profiles of $\mathrm{U}(\mathrm{VI})$ and $\mathrm{Pu}(\mathrm{IV})$ are shown in Figure 3. Note how the aqueous-phase concentration drops from stage 8 to stage 1 by almost 10 orders of magnitude, as the organic phase increases as the solvent travels from stage 1 to stage 8 . The organic-phase uranium concentration remains essential constant as the solvent passes through the two scrub stages and drops by almost 15 orders of magnitude on the strip section, providing a calculated recovery of uranium of $>99.99 \%$. The profile for $\mathrm{Pu}(\mathrm{IV})$ is quite different. Because the AHA enters the extraction section from the $\mathrm{Np} / \mathrm{Pu}$ scrub, a large fraction of the $\mathrm{Pu}$ is not extracted. The lower acid concentration and higher AHA in the Np/Pu scrub reduces the organic phase concentration of plutonium by an order of magnitude at every stage. In the second scrub, its organic-phase concentration drops slightly, and the small remnant that remains is stripped from the solvent in the $\mathrm{U}$ product. 


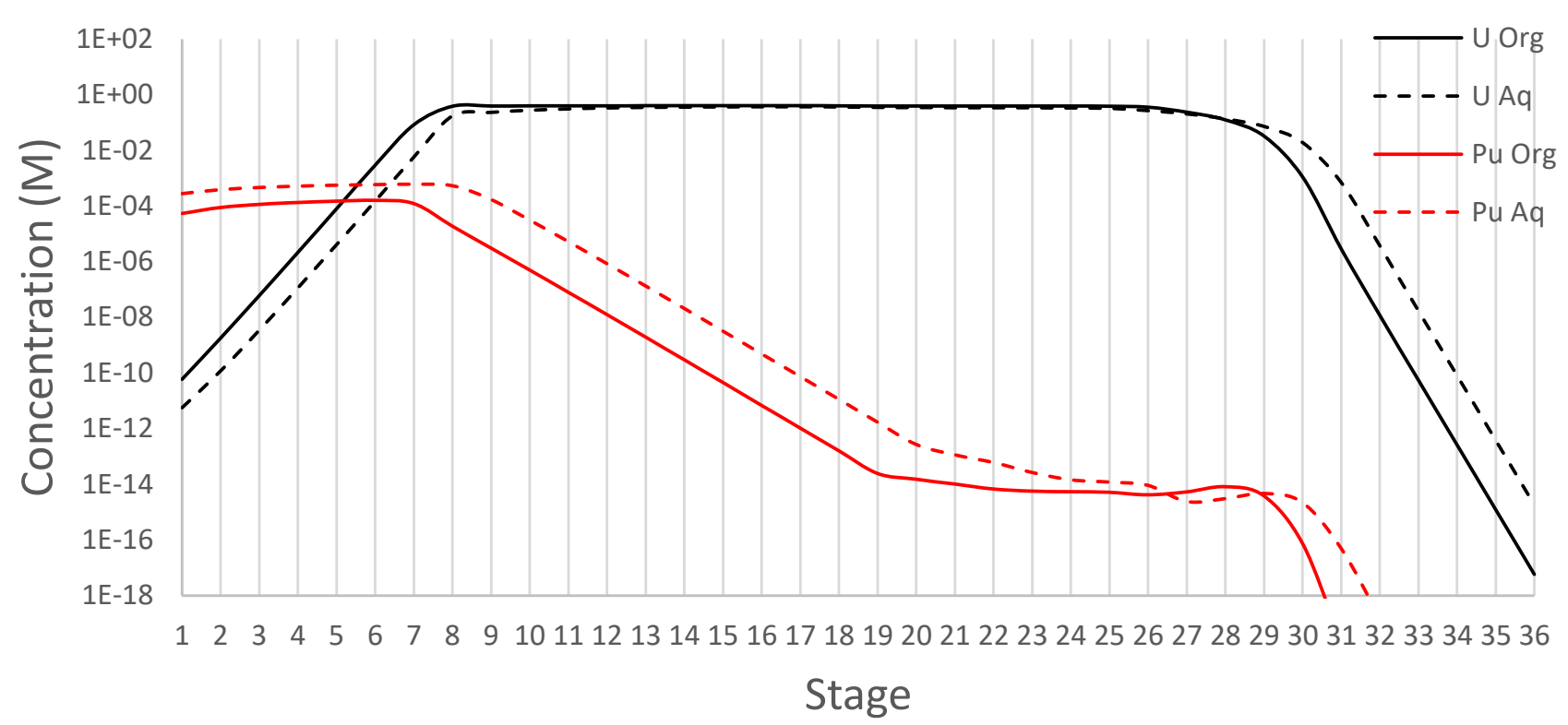

Figure 3. Equilibrium concentration profile for $\mathrm{U}(\mathrm{VI})$ and $\mathrm{Pu}(\mathrm{IV})$ at each stage.

Significant quantities of technetium and ruthenium were observed in the simulated product. However, these results do not necessarily imply poor overall decontamination. In the case of technetium, the solubility of pertechnetate $\mathrm{TcO}_{4}{ }^{-}$is very high in alkaline solutions. If the irradiated uranium is precipitated with $\mathrm{NaOH}$ after the recovery column and before UREX, the bulk of technetium can be removed with proper washing and filtration. If the hydroxide step is not implemented, technetium will prove to be a significant decontamination challenge, since it is not well retained by metal oxide sorbents like those used to capture Mo [7]. Anion exchange columns or concentrated $\mathrm{HNO}_{3}$ scrub sections have been proposed to treat U/Tc streams [24]. Likewise, ruthenium has an extremely complex aqueous chemistry and is a known contaminant across most reprocessing facilities. It has been observed in liquid (aqueous + organic), gaseous, and solid phases [11]. Various species of Ru can extract into TBP from nitric acid depending on the valence and complex of Ru, and it is not surprising that it was observed in the product. Experimental campaigns with the conditions described above should be conducted to validate this Ru behavior as well as that of other fission products, such as iodine.

Countercurrent streams of dodecane or other hydrocarbons of similar density have been proposed to strip soluble and dispersed TBP in the uranyl nitrate product [24]. Similarly, the TBP solvent can be submitted for cleanup and recycling, which may be necessary following multiple batch contacts and radiolysis effects. On the other hand, it may be more economical to periodically use fresh solvents and dispose of spent solvents as low-level waste.

\section{Processing Equipment}

Along with the contactor, a solvent-extraction process requires pumps, holding tanks, tubing, stands, motors, and room for any processing monitoring equipment; therefore, the footprint of a 
36-stage bank can be significant depending on the available facilities. Figure 4 shows a photograph of a 20-stage, 2-cm contactor bank. This particular bank is 5 feet wide. To decrease the width of a bank, contactor sections can be stacked vertically.

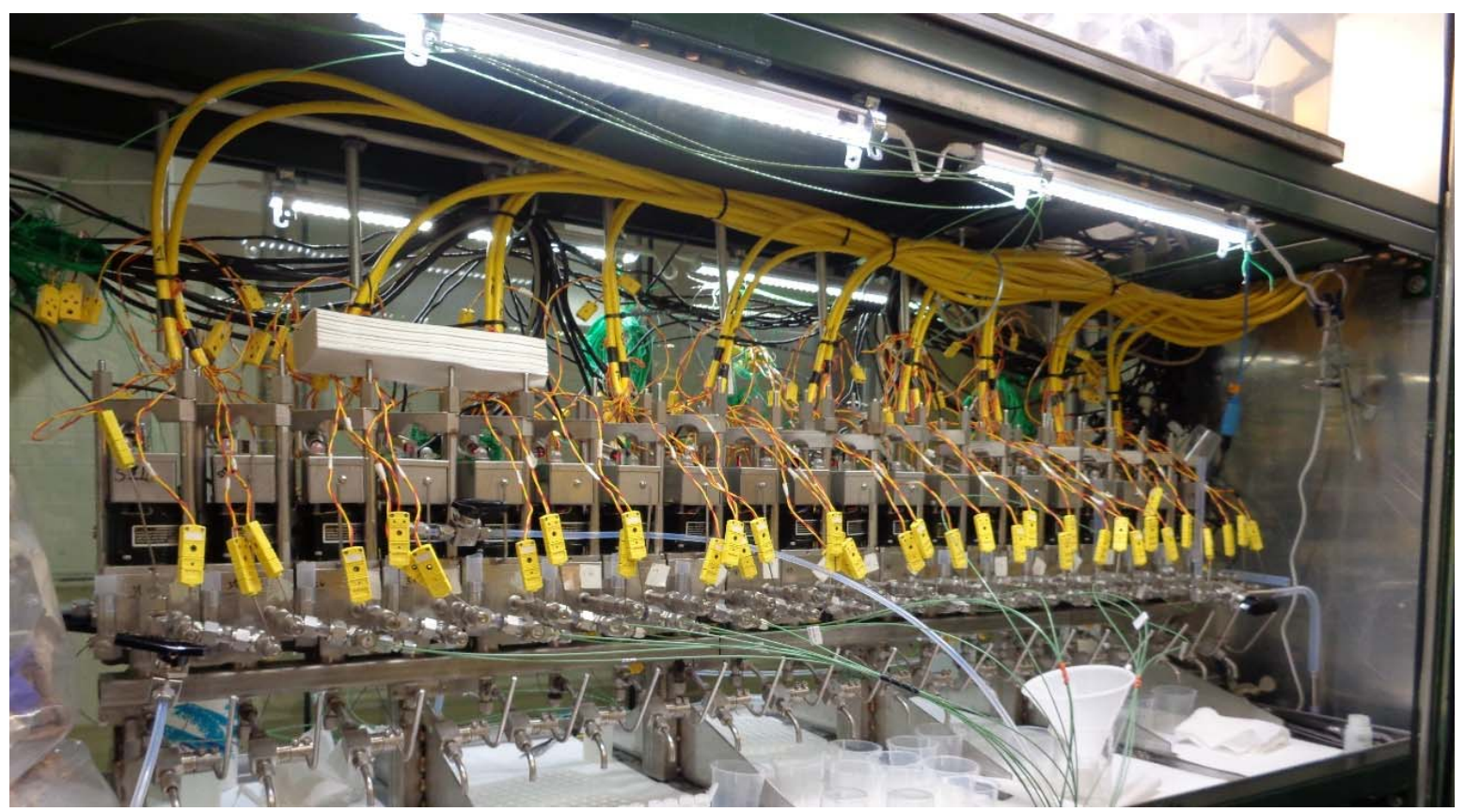

Figure 4: Photograph of a 20-stage bank of 2-cm centrifugal contactors. Provided by John F. Krebs (Argonne).

\section{Processing Time}

Processing time depends on the total feed volume, contactor throughput, contactor volume, and flow rates. Using 2-cm centrifugal contactors, the recommended maximum total flow rate is 40 $\mathrm{mL} / \mathrm{min}$ [23]. Maximum flowrates are observed in the U-strip section of this flowsheet, which means that they are $14.2 \mathrm{~mL} / \mathrm{min}$ organic and $25 \mathrm{~mL} / \mathrm{min}$ aqueous. Assuming $3.2 \mathrm{~L}$ of uranium feed per batch and an organic flow rate of $14.2 \mathrm{~mL} / \mathrm{min}$, and therefore a feed flow rate of $14.2 / 2.8=5.1 \mathrm{~mL} / \mathrm{min}$, the processing time would be 628 minutes or about $10 \frac{1}{2} 2$ hours. Startup and shutdown will add another 2-3 hours.

\section{Conclusion}

A liquid-liquid extraction flowsheet was developed to purify and recover uranium from irradiated targets that are used for ${ }^{99}$ Mo production. The flowsheet was designed using the AMUSE code, and the results show good decontamination from plutonium, neptunium, most fission products, and barrier materials along with excellent uranium recovery. A number of questions remain concerning the fission products technetium and ruthenium as product contaminants. The behavior of these elements should be experimentally investigated against the flowsheet proposed and demonstrated at full scale. 
This flowsheet is very conservative, and it may be possible to reduce the footprint by eliminating extraction and strip stages and optimizing to decrease processing time.

Because a centrifugal contactor's throughput is proportional to the diameter of the rotor to almost the third power, increasing the rotor diameter can have a significant effect on decreasing processing time. For example, a 4-cm contactor's throughput is $400 \mathrm{~mL} / \mathrm{min}$. 


\section{Conversion of the Uranium Product from the UREX Process to Uranium Metal}

Eden plans to purify the contaminated uranium generated through molybdenum recovery from targets using the UREX process described above. The composition of the uranium-strip (product) solution will likely be $0.01-0.03 \underline{\mathrm{M}} \mathrm{HNO}_{3}$ and $50-100 \mathrm{~g} / \mathrm{L}(0.2-0.4 \underline{\mathrm{M}})$ uranium as uranyl nitrate. To recycle the uranium into new targets, this solution must be converted to uranium metal. The conversion of the UREX uranium-strip solution to uranium metal is a multistep process. The two primary steps for conversion are (1) conversion of the solution to $\mathrm{UO}_{2}$ and (2) conversion of $\mathrm{UO}_{2}$ to $\mathrm{U}$ metal. Alternative technologies for each of these primary steps are discussed below.

\section{Conversion of the Uranium Product from the UREX Process to Uranium Dioxide}

A great deal of research and large-scale processing has been undertaken to convert UREX and plutonium uranium recovery by extraction (PUREX) uranium-strip solutions to uranium trioxide ( $\left.\mathrm{UO}_{3}\right)$; this work is summarized in [18], where many references to prior work are also available.

In PUREX defense plants at Hanford and Savannah River in the United States, the U product stream was converted to $\mathrm{UO}_{\mathrm{x}}$ and was sent elsewhere for further processing.

A 2013 Argonne report describes two potential processes and their associated equipment for converting UREX uranium product solution to $\mathrm{UO}_{3}$. Because the uranium was to be re-dissolved in sulfuric acid for reuse, the far-more-soluble uranium trioxide was the preferred product [3].

Other Argonne studies describe a process to generate uranium oxides from a highly radioactive uranium-containing waste solution generated from the extraction of molybdenum from dissolved uranium targets [1, 2, 4, 5]. This process will be summarized below.

Concentration and then calcination of a nitric acid solution of uranyl nitrate goes through a series of steps. Heating the solution initially drives off a vapor that is primarily water. As the water evaporates, nitric acid concentrates, and the solution's boiling temperature increases until the nitric-acid/water azeotrope is reached. When all the free water and nitric acid are removed, uranyl nitrate hexahydrate (UNH) is left in the container. The UNH then goes through a two-step dehydration, followed by denitration to $\mathrm{UO}_{3}$. Increasing the temperature to $700^{\circ} \mathrm{C}$ converts $\mathrm{UO}_{3}$ to $\mathrm{U}_{3} \mathrm{O}_{8}$. Under specific thermal conditions, the addition of hydrogen gas can reduce the $\mathrm{UO}_{3}$ to $\mathrm{U}_{3} \mathrm{O}_{8}$ and/or $\mathrm{UO}_{2}$. At temperatures above $600^{\circ} \mathrm{C}$, reduction to $\mathrm{UO}_{2}$ is the dominant reaction in a stream of $4 \% \mathrm{H}_{2} / 96 \%$ He. These reactions are shown in equations $2-7$ below:

$$
\begin{aligned}
& \mathrm{UO}_{2}\left(\mathrm{NO}_{3}\right)_{2} \cdot 6 \mathrm{H}_{2} \mathrm{O} \rightarrow \mathrm{UO}_{2}\left(\mathrm{NO}_{3}\right)_{2} \cdot 3 \mathrm{H}_{2} \mathrm{O}+3 \mathrm{H}_{2} \mathrm{O} \\
& \mathrm{UO}_{2}\left(\mathrm{NO}_{3}\right)_{2} \cdot 3 \mathrm{H}_{2} \mathrm{O} \rightarrow \mathrm{UO}_{2}\left(\mathrm{NO}_{3}\right)_{2}+3 \mathrm{H}_{2} \mathrm{O} \\
& \mathrm{UO}_{2}\left(\mathrm{NO}_{3}\right)_{2} \rightarrow \mathrm{UO}_{3}+2 \mathrm{NO}_{2}+1 / 2 \mathrm{O}_{2}
\end{aligned}
$$




$$
\begin{aligned}
& 3 \mathrm{UO}_{3} \rightarrow \mathrm{U}_{3} \mathrm{O}_{8}+1 / 2 \mathrm{O}_{2} @ 700^{\circ} \mathrm{C} \\
& 3 \mathrm{UO}_{3}+\mathrm{H}_{2} \rightarrow \mathrm{U}_{3} \mathrm{O}_{8}+\mathrm{H}_{2} \mathrm{O} \\
& \mathrm{UO}_{3}+\mathrm{H}_{2} \rightarrow \mathrm{UO}_{2}+\mathrm{H}_{2} \mathrm{O}
\end{aligned}
$$

The bench-scale equipment described in these reports was appropriate for conversion of these solutions, which contain up to $600 \mathrm{~g}$ of uranium in a vessel roughly the size of a 12-ounce soda can. Schematics of the equipment and calciner cup are shown in Figure 5 and Figure 6. Figure 7 is a photograph of the experimental setup. Experimental details can be found in the references mentioned above (1, 2, 4, 5 in References).

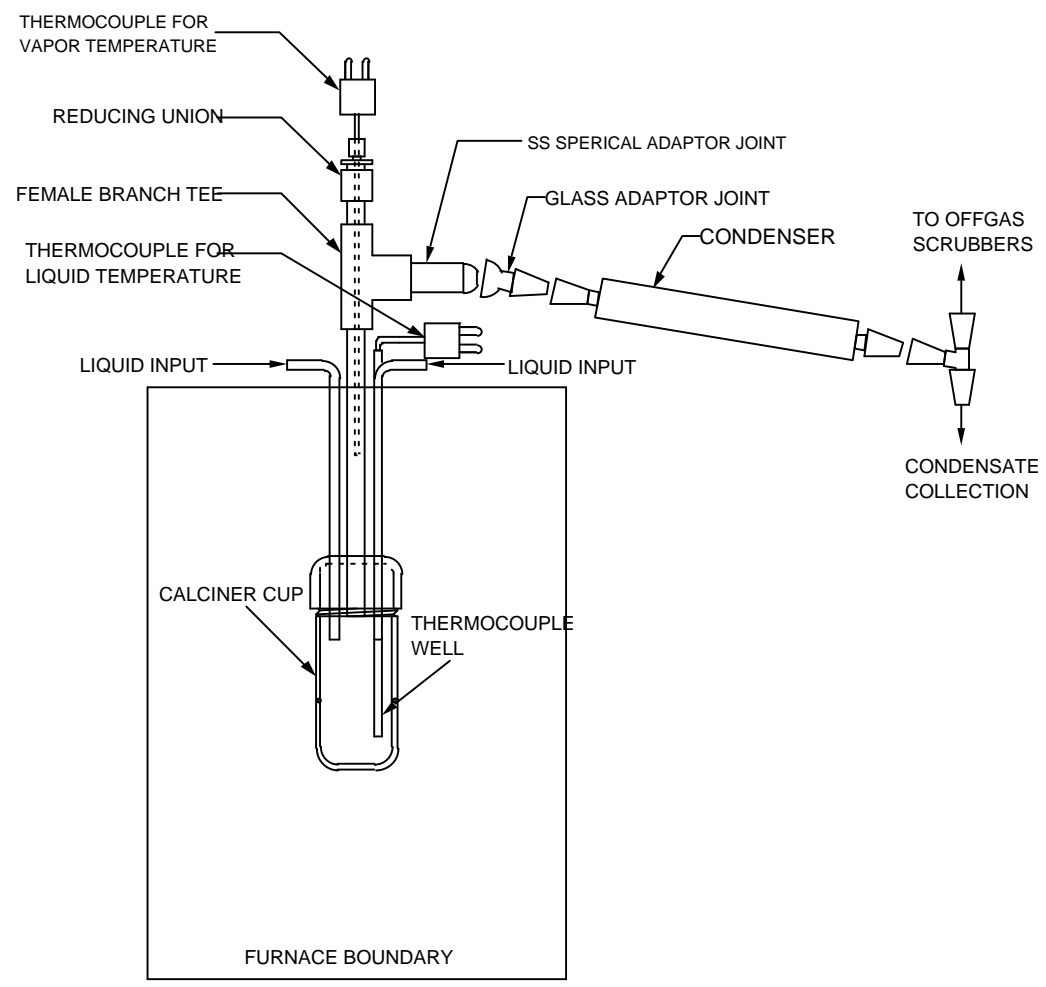

Figure 5. Schematic of calciner equipment. 


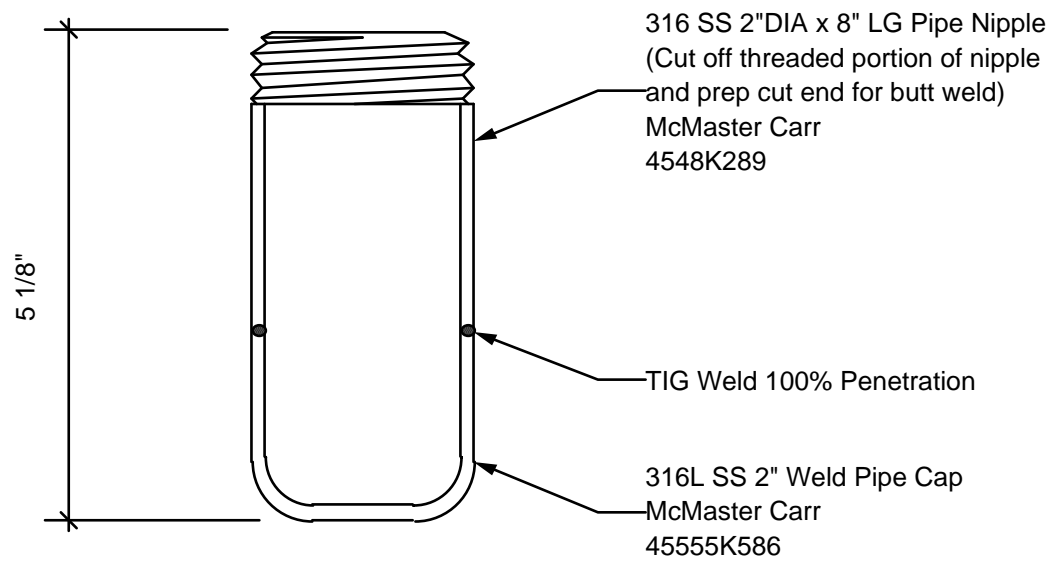

Figure 6. Detail of calciner cup.

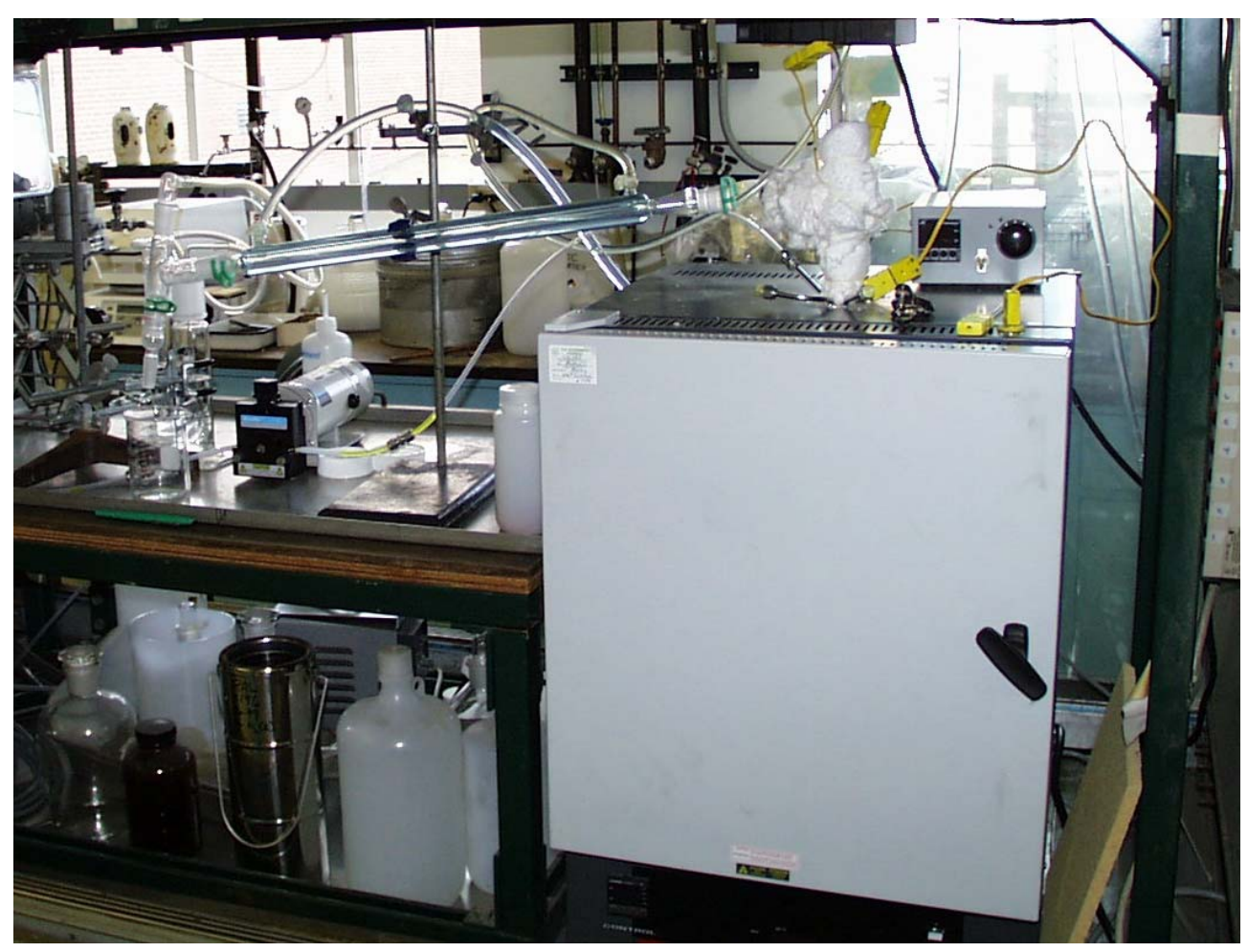

Figure 7. Overall view of lab-scale experimental calcining system.

The low melting point $\left(60.2^{\circ} \mathrm{C}\right)$ of $\mathrm{UNH}$ [16] has a profound negative effect on its calcination. Molten $\mathrm{UNH}$ is highly viscous, the evolution of water and $\mathrm{NO}_{2}$ during its destruction causes a great deal of sputtering and splattering, and the product uranium oxide is a non-friable porous cake that is not easily removed from the calcine vessel. For these reasons, the authors of the study looked for additives that would reduce sputtering and would form a granular product, including formic acid, hydrogen peroxide, and oxalic acid. These reagents have the ability to 
release nitrate from the $\mathrm{UNH}$ and allow the nitrate to be evaporated from the calciner as nitric acid and/or be reduced to $\mathrm{NO}_{2}$. In this process, they precipitate the bulk of the uranium as uranyl salts. Evaluation of each of these reagents showed that the use of oxalic acid was most promising.

Based on these studies, the addition of oxalic acid would have three benefits for Eden: (1) eliminating sputtering and greatly reducing contamination of equipment outside the calcine can, (2) producing a granular/friable product that could easily be removed from the can, and (3) producing $\mathrm{UO}_{2}$ when used in conjunction with hydrogen gas at $600^{\circ} \mathrm{C}$. The only downside to the use of oxalic acid is that the product is less dense than the direct-calcination product and would require nearly twice as large a can volume. However, the goal of these previous studies was to develop a process in which the calciner can was the storage container for the uranium/fissionproduct waste and was meant for ultimate disposal; therefore, minimizing the volume of the container was important. For a process in which the uranium would be recovered and the calciner reused, this should not be a serious concern. Chemical reactions that are in play with the addition of oxalic acid are the following:

$$
\begin{aligned}
& \mathrm{UO}_{2}\left(\mathrm{NO}_{3}\right)_{2}+\mathrm{H}_{2} \mathrm{C}_{2} \mathrm{O}_{4} \rightarrow \mathrm{UO}_{2} \mathrm{C}_{2} \mathrm{O}_{4}+2 \mathrm{HNO}_{3} \\
& \mathrm{UO}_{2} \mathrm{C}_{2} \mathrm{O}_{4} \rightarrow \mathrm{UO}_{3}+\mathrm{CO}_{2}+\mathrm{CO} \\
& \mathrm{UO}_{2} \mathrm{C}_{2} \mathrm{O}_{4} \rightarrow \mathrm{UO}_{2}+2 \mathrm{CO}_{2} \\
& 3 \mathrm{UO}_{2} \mathrm{C}_{2} \mathrm{O}_{4}+\mathrm{O}_{2} \rightarrow \mathrm{U}_{3} \mathrm{O}_{8}+6 \mathrm{CO}_{2} \\
& \mathrm{UO}_{2}+2 \mathrm{UO}_{3} \rightarrow \mathrm{U}_{3} \mathrm{O}_{8} \\
& 3 \mathrm{UO}_{2}+\mathrm{O}_{2} \rightarrow \mathrm{U}_{3} \mathrm{O}_{8} \\
& \mathrm{H}_{2} \mathrm{C}_{2} \mathrm{O}_{4} \rightarrow \mathrm{H}_{2} \mathrm{O}+\mathrm{CO}+\mathrm{CO}_{2} \\
& \mathrm{H}_{2} \mathrm{C}_{2} \mathrm{O}_{4}+2 \mathrm{HNO}_{3} \rightarrow 2 \mathrm{CO}_{2}+2 \mathrm{H}_{2} \mathrm{O}+2 \mathrm{NO}_{2}
\end{aligned}
$$

In these experiments, two methods for adding oxalic acid were studied. The first method was to add solid oxalic acid to the can before flowing the uranium solution into the calciner during heating. The second was to flow the uranium solution into the calciner while heating and continue the flow and heating until no more condensate was seen. At this point, an aqueous solution of oxalic acid was fed into the calciner, and evaporation continued until no $\mathrm{HNO}_{3}$ or $\mathrm{NO}_{\mathrm{x}}$ was seen in the off gas.

The first method has the advantages of simplicity, reduced liquid waste, and shorter processing time. However, (1) the volume of the calciner cup will limit the amount of oxalic acid that can be added and (2) there is a partial loss of oxalic acid (equations 14 and 15). The second method 
does not limit the amount of oxalic acid that can be used in the process, and less oxalic acid is needed for the process. However, the limited solubility of oxalic acid $(\sim 1 \underline{\mathrm{M}})$ requires a large volume of liquid to be added to the calciner - which means more liquid waste and longer processing times due to the evaporation of the additional volume of water.

\section{Conversion of Uranium Dioxide to Uranium Metal}

Once the uranyl nitrate solution is calcined to yield uranium dioxide, the next step is to convert the oxide through a nonaqueous process to metallic uranium. A 2008 Argonne report provided flowsheets, process descriptions, and material balances (including waste streams) for a baseline and alternative method to convert uranium dioxide to uranium metal for a $2000 \mathrm{~kg} / \mathrm{y}$ facility. In addition, the report provided a brief description of the process equipment, a facility layout, and cost estimate for each conversion method [8]. A brief description of the processes is discussed below. The reader is referred to that extensive report for particulars.

\section{Baseline Conversion Process}

The baseline process consists of two well-established unit operations for converting uranium dioxide to uranium metal: hydrofluorination and calciothermic reduction. They are routinely used in the uranium enrichment and metal production processes. Over the years, the chemistry and engineering of these processes have been optimized to yield high-quality product while minimizing waste production.

The hydrofluorination process converts uranium dioxide to uranium tetrafluoride by reaction with hydrogen fluoride gas. The chemical equation describing the process is the following:

$$
\mathrm{UO}_{2}(\mathrm{~s})+4 \mathrm{HF}(\mathrm{g}) \rightarrow \mathrm{UF}_{4}(\mathrm{~s})+2 \mathrm{H} 2 \mathrm{O}(\mathrm{g})
$$

This solid-gas reaction is typically completed in a fluidized-bed reactor at temperatures in the range $300^{\circ} \mathrm{C}$ to $500^{\circ} \mathrm{C}$. Complete conversion of the $\mathrm{UO}_{2}$ to $\mathrm{UF}_{4}$ is routinely achieved on an industrial scale.

The calciothermic reduction process chemically reduces the $\mathrm{UF}_{4}$ with calcium metal to produce uranium metal. The chemical equation describing the process is as follows:

$$
\mathrm{UF}_{4}(\mathrm{~s})+2 \mathrm{Ca} \rightarrow \mathrm{U}(\mathrm{s})+2 \mathrm{CaF}_{2}(\mathrm{~s})
$$

The reduction process is carried out in a batch reactor with a reaction initiation temperature of approximately $500^{\circ} \mathrm{C}$. The enrichment level of the feed material and equipment design dictate batch size. As with the hydrofluorination process, complete conversion of the $\mathrm{UF}_{4}$ to $\mathrm{U}$ is routinely achieved on an industrial scale. The product metal is separated from the $\mathrm{CaF}_{2}$ and residual Ca in a billet-salt separation process. This mechanical operation removes the residual salt from the reduced metal to produce a clean ingot. 
In addition to the major $U$ conversion operations, there are auxiliary operations required to deliver the reagents and condition the waste streams. These supporting operations include the HF vaporizer for the hydrofluorination system, the off-gas treatment system, reduction vessel cleaning, and product and waste storage.

\section{Electrochemical Reduction Process}

An alternative conversion method for the conversion of $\mathrm{UO}_{2}$ to uranium is the electrochemical reduction of uranium dioxide to yield uranium followed by a salt-metal separation process [9, 21]. The electrochemical (or electrolytic) reduction process involves loading the $\mathrm{UO}_{2}$ into a basket that functions as the cathode in the electrochemical cell. The basket containing the $\mathrm{UO}_{2}$ is then immersed in molten $\mathrm{LiCl}$ that contains $1 \mathrm{wt} \% \mathrm{Li}_{2} \mathrm{O}$. As current is passed between the cathode and anode of the cell, uranium ions in the $\mathrm{UO}_{2}$ are reduced to uranium metal, and oxide ions are liberated to the salt phase. Simultaneously, oxide ions are oxidized at an inert anode to produce oxygen gas that is swept from the cell. The resulting metallic product is removed from the cathode and treated in a furnace to remove the salt adhering to the metal and, ultimately, melt the uranium into a billet.

The advantages of the electrolytic reduction process compared to hydrofluorination and calciothermic reduction include:

- Limited need for chemical reagents, because the process uses electrons for the oxideto-metal conversion

- Reduced process waste, since no HF and no reductant metal or one-time-use liners are needed

- Enhanced process safety due to no HF or steam handling requirements

- Reduced process footprint

Its major disadvantage is the lack of decades of experience in its use.

\section{Uranium Metal to Targets}

Once the uranium metal is formed into billets, additives must be added to the uranium, the uranium must be rolled into foils, and targets must be fabricated. An Argonne report published in 2009 looked at target fabrication [23]. The report documents a high-level study to designate the unit operations and considerations that would be required in a facility designed to meet the next decade of U.S. demand for ${ }^{99}$ Mo using LEU annular foil targets. The goal of this report was to give a commercial enterprise interested in pursuing production of targets enough information to (1) understand what is required in the facility and (2) perform a high-level cost estimate to build and operate the facility. 


\section{Conclusions}

The UREX process can be used to recovery and purify LEU from irradiated targets for the production of fission-product ${ }^{99} \mathrm{Mo}$. Use of a centrifugal contactor will minimize space requirements and processing time. Following recovery and purification, the U-product solution from the UREX process must be converted to $\mathrm{UO}_{2}$ and then to $\mathrm{U}$ metal to allow recycling into new targets.

Evaporation/calcination is an available small-scale low-technology option for converting the UREX uranium product to a solid uranium oxide. The addition of oxalic acid to the operation will provide a friable granular product that can be removed from the calciner for the next operation. Without the use of a final reduction of the oxide with hydrogen gas, the product would be a mixture of $\mathrm{U}_{3} \mathrm{O}_{8}$ and $\mathrm{UO}_{2}$, which would be a form appropriate for shipping to another facility for follow-up operations for conversion to $\mathrm{UO}_{2}$ and then to metal, and eventually to target manufacture. If a follow-on step to the calcination operation of flowing a steam of $4 \% \mathrm{H}_{2} / 96 \%$ $\mathrm{He}$ into the calciner at $600^{\circ} \mathrm{C}$ is performed, the $\mathrm{UO}_{2}$ will be suitable for in-house reduction to uranium metal.

Two methods are available for this reduction - the classical method of hydrofluorination and calciothermic reduction or electrochemical reduction. The electrochemical reduction process has attributes that make it a better choice for the small-scale operation envisioned for Eden.

Follow-up steps are required for treatment of the uranium product from UREX to prepare uranium dioxide suitable for conversion to metallic uranium. Further development will be required to meet this goal. Once the composition of the uranium strip is established, equipment and conditions must be optimized to consistently prepare a suitable $\mathrm{UO}_{2}$ product, at the rate necessary to meet Eden's requirements.

If Eden also plans to convert $\mathrm{UO}_{2}$ to metal in house, additional development will also be required for this operation. 


\section{References}

1. Bakel, A. J., K. J. Quigley, and G. F. Vandegrift. 2002. Argonne National Laboratory Progress in Minimizing Effects of LEU Conversion on Calcination of Fission Product ${ }^{99} \mathrm{Mo}$ Acid Waste Solution. Presented at 2002 International RERTR Meeting, San Carlos de Bariloche, Argentina.

2. Bakel, Allen J., George F. Vandegrift, Kevin J. Quigley, Scott B. Aase, Michael K. Neylon, Kevin P. Carney, and A. Travelli. 2003. ANL Progress in Minimizing Effects of LEU Conversion on Calcination of Fission-Product ${ }^{99}$ Mo Acid Waste Solution. Presented at 25th International Meeting on Reduced Enrichment for Research and Test Reactors, Chicago IL.

3. Bakel, Alan J., and George F. Vandegrift. 2013. Equipment and Method Choices for Concentration and Denitration of the Uranium Product from UREX. https://doi.org/10.2172/1091499.

4. Bakel, Allen J., Cliff J. Conner, Kevin J. Quigley, and George F. Vandegrift. 2016. Waste Treatment of Acidic Solutions from the Dissolution of Irradiated LEU Targets for ${ }^{99} \mathrm{Mo}$ Production. https://doi.org/10.2172/1328741.

5. Bakel, Allen J., Cliff J. Conner, Kevin J. Quigley, and George F. Vandegrift. 2017. Gas Generation During Waste Treatment of Acidic Solutions from the Dissolution of Irradiated LEU Targets for ${ }^{99}$ Mo Production. https://doi.org/10.2172/1343093.

6. Benedict, M., T. Pigford, and H. Levi. 1981. Nuclear Chemical Engineering, 2 Ed. New York: McGraw-Hill Education.

7. Eden Radioisotopes. Company Overview. 2019. Presented at NNSA Stakeholders Meeting, Chicago, IL. https://mo99.ne.anl.gov/2019stakeholders/

8. Figueroa, J., and M. A. Williamson. 2008. Uranium Dioxide Conversion. https://publications.anl.gov/anlpubs/2014/09/106366.pdf

9. Ganzerli-Valentini, M. T., et al. 1973. "Radiochemical Separations by Adsorption on Some Oxides of Groups IVB and VB.” Journal of Radioanalytical and Nuclear Chemistry 16: 191204.

10. Gourishankar, K., L. Redey, and M. Williamson. 2002. Electrochemical reduction of metal oxides in molten salts. In Light Metals 2002: Proceedings of the Technical Sessions Presented by the TMS Aluminum Committee at the 131st TMS Annual Meeting, Seattle, Washington, February 17-21, 2002, edited by W. A. Schneider, 1075-1082. Warrendale, PA: Minerals, Metals \& Materials Society.

11. International Atomic Energy Agency. 1995. Alternative Technologies for ${ }^{99}{ }^{9} c^{m}$ Generators. Vienna: IAEA.

12. Leonard, R. A., D. B. Chamberlain, and C. Conner. 1997. "Centrifugal Contactors for Laboratory-Scale Solvent Extraction Tests.” Separation Science and Technology 32 (1-4): 193-210. https://doi.org/10.1080/01496399708003194.

13. Leonard, R. A. 1988. "Recent Advances in Centrifugal Contactor Design." Separation Science and Technology 23 (12-13): 1473-1487. https://doi.org/10.1080/01496398808075643. 
14. Pruett, D. J. 1984. "Extraction Chemistry of Fission Products.” In Science and Technology of Tributyl Phosphate, edited by W.W. Schulz, et al., 82. Boca Raton, FL: CRC Press, Inc.

15. Regalbuto, M., et al. 2004. "Solvent Extraction Process Development for Partitioning and Transmutation of Spent Fuel.” In Actinide and Fission Product Partitioning and Transmutation: 8th Information Exchange Meeting, 373-385.

16. Science Lab.com. 2013. Material Safety Data Sheet: Uranyl nitrate hexahydrate MSDS. http://www.tn.edu/ehs/msds/u/Uranyl\%20Nitrate.pdf.

17. Service, R. F. 2011. “Scrambling to Close the Isotope Gap.” Science 331: 277-279. https://doi.org/10.1126/science.331.6015.277.

18. Vandegrift, George F. 2000. Transformation of UREX Effluents to Solid Oxides by Concentration, Denitration, and Calcination. https://doi.org/10.2172/775265.

19. Vandegrift, G., F., et al. 2004. Designing and Demonstration of the UREX+ Process Using Spent Nuclear Fuel. Presented at ATALANTE 2004, Nîmes, France.

20. Vandegrift, George F., Laura Maggos, Candido Pereira, James Jerden, and Delbert Bowers. 2012. Letter Report: UREX Flowsheet for Cleanup of a Spent $130 \mathrm{~g}$-U/L Uranyl Sulfate SHINE Target Solution. https://doi.org/10.2172/1131393.

21. Vandegrift, George F., et al. 2016. Low-Enriched Uranium High-Density Target Project: Compendium Report. https://doi.org/10.2172/1331365.

22. Westphal, B. R., J. R. Krsul, and D. W. Maddison. 2002. "Molten Salt Separation form Uranium During the Processing of Spent Nuclear Fuel.” In Light Metals 2002: Proceedings of the Technical Sessions Presented by the TMS Aluminum Committee at the 131st TMS Annual Meeting, Seattle, Washington, February 17-21, 2002, edited by W. A. Schneider, 5762. Warrendale, PA: Minerals, Metals \& Materials Society.

23. Wiencek, T. C., G. F. Vandegrift, and A. Bakel. Conceptual Process and Facility Design to Produce Low-Enriched Uranium Targets for the Production of ${ }^{99}$ Mo Medical Radioisotopes. https://publications.anl.gov/anlpubs/2013/10/77307.pdf. 


\section{Argonne}

Chemical and Fuel Cycle Technologies Division

Argonne National Laboratory

9700 South Cass Avenue

Argonne, IL 60439

www.anl.gov 